\title{
The Melodramatic Narrative and Ontological Quest in Demetria Martínez’s Mother Tongue
}

\author{
Euna Lee \\ Institute of Latin American Studies, Seoul, Korea
}

\begin{abstract}
The study deals with Demetria Martínez’s Mother Tongue (1994), which is a love story between a Mexican American woman and a Salvadoran refugee. The female protagonist, Mary, delves into connotations of love, expanding it to understanding of the other. The story deploys politically imbricated religious practices in relation to the U.S. Sanctuary movement in the 80s. Mary’s amorous encounter with the other leads her to discover the expansion of friendship and solidarity and, ultimately to rediscover religiosity based on reawakened ethics. This study argues that the melodramatic mode employed in this novel implicitly reveals an inherent aspiration for the sacred, albeit not fully representable. The author's involvement in the genre of romance and the melodramatic mode ironically attests to her striving for the spiritual ideal and ontological answer. In the end, this essay reveals that drawing on the popular melodramatic narrative, the romantic engagement with the alterity can be more efficiently introduced into the ontological quest for the absolute presence.
\end{abstract}

Keywords: Demetria Martínez, Mother Tongue, romance, melodramatic narrative, solidarity, ontological quest

\section{Introduction}

At first glance, Demetria Martínez’s Mother Tongue is a love story. It portrays romantic pain accompanied by political turmoil in Latin America which is eloquently elaborated mainly from a female perspective. The story also deploys politically imbricated religious practices but conveys them in the form of romance. Mary, the protagonist, helps a Salvadorian refugee, José Luis, a former seminary student, to adjust in the U.S. society. The romantic encounter with José Luis gradually requires Mary's involvement in diverse cultural and political configurations which have been an unknown realm to her. In the chapter of "Solidarity", Debra Castillo explains that Mary's experience and José Luis's are not translatable into each other due to constraints of language and culture as well as class, privilege, and vastly different circumstances (Castillo \& Tabuenca Córdoba, 2002, pp. 168-188). José Luis offers a matrix interwoven with complex issues such as religion, race, gender, and politics totally foreign to her. Mary's reaction to this relation reflects contemporary philosophical debates that circle around the question of the other as an emblematic figure representing difference, plurality, and strangeness. The author intends to reposition the others who are Central American political refugees and those involved in the U.S. Sanctuary movement who aid them.

Euna Lee, Ph.D., HK Professor, Institute of Latin American Studies.

This work is supported by the National Research Foundation of Korea Grant (NRF-2008-362-B00015). 
One of the defining features of Mother Tongue is its overwhelming preoccupation with romantic love. Romance occupies center stage in this novel, yet it also functions as an absent presence. It is a marker for a place that remains empty, a measure of how much the Salvadorian war took away from the people it touched. In addition to romance ${ }^{1}$, another characteristic manifest in the novel is melodramatic narrative. I want to investigate the relation between Martínez's usage of this genre and her transcendental aspiration, by recourse to Peter Brooks's principal idea of The Melodramatic Imagination. Erotic love in the melodramatic mode in this novel can be interpreted as a hidden "nostalgia for religion". This study will show how the failure of romance brings Mary into existential confrontation with herself that reawakens ethical involvement in solidarity and politics.

\section{Romance and Melodramatic Mode}

According to Brooks, the melodramatic mode is symptomatic of an era in which there are no more distinct polarizations of value sustained by the sacred. He suggests that melodrama needs to be seen as a modern attempt to dramatize spiritual meaning in the absence of an overarching notion of the sacred. He argues that "melodrama represents both the urge toward resacralization and the impossibility of conceiving sacralization other than in personal terms” (Brooks, 1995, p. 16). Brooks analyzes that authors have recourse to the demonstrative, heightened representations of melodrama when they continue to want to literalize ethical drama and the ethical implications (Brooks, 1995, p. 21). Melodramatic rhetoric is one of extremes, of hyperbole, sensationalism, and exaggeration. Melodrama, characterized by moral polarities, implausible plots, and rhetorical exaggeration, is thus defined less by a distinctive narrative or thematic logic than by a mode of aesthetic presentation. Analyzing the relationship between dominating modes of their novels and literary intensions, Brooks shows that by drawing on melodramatic techniques, authors replace the absent sacred order with the realm of distinct polarizations on which melodrama is founded. As a result, he basically attempts to retrieve a creative intention that lies beneath literary motives from melodrama, which is considered a degraded genre.

In this vein, Mother Tongue's dependency on this mode is intended to reveal that the extreme progress of the passion leading to an expected ending seeks to attain something else, although it does not ostensibly intend to grasp the whole of it. Regardless of agreeing with Brooks's explication, it is true that the melodramatic mode in this novel facilitates the linking of romance with political and religious exploration. Thus, Mary's romantic encounter with the alterity can be more efficiently introduced into her ontological search by dealing with popular romance.

Two layers of romantic structure governs the novel: that of the protagonist, Mary and that of the author, Martínez. Utilizing the genre of romance, Martínez lets Mary follow an over determined ${ }^{2}$ plotline of romantic love. In the first stage of the story, Mary presents herself as a woman who is willfully affected by the discourse and ideology of romance. By instilling herself with false security, she attempts to transcend the ordinariness of life, which she has conceived as the disinterestedness of divine figures. Her emotional attachment to romance

\footnotetext{
1 The story can be termed as popular romance. The popular romance embodied in the novel can be characterized as exotic romance, borderlands romance, or historical romance in accordance with the perspective from which the love is highlighted.

2 Rachel Blau Duplessis, in Writing beyond the Ending, explains about what “story” for women means: “'Story' for women has typically meant plots of seduction, courtship, the energies of quest deflected into sexual downfall, the choice of a marriage partner, the melodramas of beginning, middle, and end, the trajectories of sexual arousal and release” (Duplessis, 1985, p. 151). I want to use the characteristics of this "story" as overdetermined. This "story" coincides with what Mary refers to while mentioning love.
} 
contradictorily tells that her real motivation to follow the romantic routine leading to the traditional notion of marriage, is, in fact, romance narrative per se: “a limit-breaking genre, a genre of excess” (Heller, 1995, p. 221) which nonetheless contains patriarchal relations as well as a site of resistance to it. Hoping to be faithful to the ideological character of the romance plot, she dreams of marriage with José Luis according to her romance encoding, which she eventually has to contest.

Later, Mary enacts renewal of romance in her own way while recalling a history that encompasses her whole discovery of gender, politics, and culture. Her revision of romance is, in fact, equated with her awakening of identity. The author's interrogation of marriage-and-family plots, institutions, and narrative forms coincides with this radical awakening. After José Luis's departure, Mary is more involved in the process of formulating herself through resignifying romance. She gradually changes by estranging herself from the fictionally-given plot so as to subvert the identity that has been displaced there. When an aging Mary decides to unveil the past in order to shape her own life, the novel opens up the space in which romance can empower woman to assume a different role in love and history in the last stage. In other words, this resignified romance produces the new Mary, to which she gives birth at the end of the novel. Thus, this Mary has a consciousness liberated enough to leave behind the reality of fiction.

According to Susan Strehle's definition of historical romance in Doubled Plot, Mary follows the role of a woman who "experiences primarily the reassuring and comforting aspects of her romance, but in the retrospective mode, she comes to explore forms of damage created by heterosexual love" (Strehle \& Carden, 2003, p. 32). By conjoining a fractured love story with a historical tale of war, the novel suggests that woman's role as lover emerges from those of an observer and a victim of that history:

I would not understand the sentiments actually expressed in those words until much later when I understood love could not be divorced from history, that his war had to become my war. (Martínez, 1994, p. 44)

Mary becomes a woman who loses what she holds most dear in the upheaval of history and whose story rethinks the systems and values sustained by the romance plot. Women writers such as Julia Alvárez and Edwidge Danticat, among others, explore the ways in which female characters are instilled with the expectations of traditional romance in the midst of political upheavals. Likewise, Mary's intimate story simultaneously explores the sphere of the historically important occurrence. While concerned with the nature of tragic romance, Martínez portrays Mary's gradual involvement in the political world, calling attention to the intricacy of their connection between two different worlds,the Chicana world and the Central American one. Even though the borderland in the novel does not refer to the Mexican-American region, the contact entails analogous political hierarchies of the North and the South and portrays the geographical importance of the Southwest as a place for illegal immigrants and political refugees. Finally, the narrative gets to delineate the activism of the Chicana resisting against romantic plot that has imperceptibly inhibited her political, ideological, and cultural awakening.

In the first stage of the novel, Martínez deliberately attempts to induce readers to realize how powerfully and negatively the romance plot is inscribed on Chicanas' lives and values, while tracing the centrality of the romantic script in individual and communal self-definition. She treats romance as both a fulfillment of myth and a rebellion against it: 
Love at first sight, this is how I explained the urgency that would later shed its skin and reveal pure desperation. Some women fall in love in advance of knowing a man because it is much easier to love a mystery. And I needed a mystery — someone outside of ordinary time who could rescue me from an ordinary life, from my name, Mary, a blessing name that had become my curse. At age nineteen, I was looking for a man to tear apart the dry rind of that name so I could see what fruit fermented inside. (Martínez, 1994, p. 16)

From the beginning, Mary desires to deviate from the way of life in which she has regarded herself as predetermined. This motivates her to explore an unknown world: the world foreign to her, thus, should be exotic and mythic so that she can get rid of her "cursed" ordinariness.

The original reason Mary depends on the romantic plot is her realization that she lacks a myth or story that could offer her a meaningful sense of life. She confesses, "women who fall asleep and don't know why lack a plot line; this is the secret source of their shame. I concocted a plot of my own, orchestrating what I could until characters began to say and do things I had never imagined, me included” (Martínez, 1994, p. 27). Her awareness of the enormous lack of a "story" in her life ironically impels her to invent a role of overdependence upon winning love to achieve self-worth through a self-sacrificing persona. She decides to credit this kind of story in order to "rescue herself from an ordinary life, from her name, Mary, a blessing name that had become her curse" (Martínez, 1994, p. 16). Later, she admits that she did not know why, but she definitely expected something Olmec: "African features and a warrior's helmet as in those sculpted basalt heads, big as boulders, strewn on their cheeks in Mesoamerican jungles” (Martínez, 1994, p. 4).

What is intriguing about this novel is that the protagonist allows readers to be aware of the fact that she clearly accepts her chaos as an ontological condition but, nevertheless, attempts to find an easy solution in cliché in a mythic romance. In other words, Mary simply wants to confront her problem in a conventional way by relying on an already-made romantic framework. For performing in response to the mythic imagination, she only refers to her own culture's myths. The author chooses as archetypes the goddess Ishtar and La Malinche. Ishtar is employed as a feminist spiritual concept and La Malinche as a translator figure. Mary allows herself to become subject appropriating these mythic figures to be faithful in fulfillmentof what these mythic figures are expected to perform. She confesses that "A center so far away from God that I asked forgiveness in advance, remembering words I'd read somewhere, words form the mouth of Ishtar: A prostitute compassionate am I” (Martínez, 1994, p. 5). This gives credence to her interpretation of these archetypal narratives as a significant source of tension and seduction despite the lack of actuality in the present. Martínez elucidates this by saying, "as Ishtar takes the war out of men when they come to the temple after having been to war, later in the novel, Ishtar reappears as the Mother of Disappeared" (Ikas, 2002, p. 122). The identification with La Malinche implies that Mary's willingness and vulnerability in sexual engagement will be intertwined with shame and self-contempt.

Following these mythic scripts, Mary imagines herself as a lover who falls in love with a warrior and rescues him from war. In her fictional imagination, José Luis supposedly has to be the one who provides alternative absolute significance with her. However, her own mythic plot cannot escape the predetermined tragic ending since this myth is ensured by her acknowledgement that she is “utterly unoriginal” (Martínez, 1994, p. 27). By admitting her unoriginality, she implies that her plot is doomed to fail.

Then, why does Martínez seem to espouse the banality and clichés that these mythic stories retain? Do Chicanas indeed intend to get back to archetypal figures in order to envision what they are looking for? Rachel 
Blau Duplessis, while analyzing tactics of revisionary mythopoesis, asserts that "the poet's attitude toward the tale as given determines whether there will be a displacement of attention to the other side of the story, or a delegitimation of the known tale, a critique even unto sequences and priorities of narrative” (Duplessis, 1985, p. 108). For the same purpose, Martínez makes use of Mary’s naïveté and estranges readers from the inner norms of the myths as well as of the world in which Mary lives.

Mary tries to prove that "myth making could now only be individual, personal” (Brooks, 1995, p. 16). However, when she says, "You see, the fear I am best at is always based upon a myth” (Martínez, 1994, p. 90), she is not referring to the personal myth that she forces herself to create later through storytelling, but an imposed myth. As opposed to this inherited myth, she dreams of a myth left to personal construction while implying that myth making is the only way of understanding the truth. For her, "personal myth" is yet to be created. Anonymous “collective myth" in the ethnological sense, as I use the term, points to a story that states specific cultural agreement and coherence. Contrasting the collective with the personal ironically highlights that myth is still working as an influential significance with a different structural dimension. Mary's seemingly obsessed longing for personal myths is paradoxically intended to reveal the urge for “resacralization” in Brooks's term. Ultimately, Mary aspires to reconstruct her own myth for the very purpose of rediscovering a sense of memorability and significance in her life. By revealing this, the author reasserts Mary’s renewed thirst for the sacred.

Mary feels that the ordinariness of reality can be equated with the world voided of a true sacred. According to Clifford Geertz ${ }^{3}$, the sacred bears a sense of intrinsic obligation: "it not only encourages devotion, it demands it; it not only induces intellectual assent, it enforces emotional commitment” (Geertz, 1973, p. 126). In spite of her willingness to have faith, she cannot find these natures of the sacred in official religion: "I was nineteen, young enough to believe I had outgrown the walls of San Rafael Church. North American to the core, a consumer, I saw religion as a bazaar from which I could pick and choose” (Martínez, 1994, p. 25). Mary considers religion as something one can consume and shop for. Likewise, she witnesses the loss of belief in the reality of the invisible and contemporary nihilism in conflict with religious doctrine, which underscores the contradictions in romantic concepts of subjectivity.

A series of desperate expressions employed by Mary, in aspiring to more intimacy with José Luis, is related to recovery of the sacred presence or intervention in her life. Therefore, through the figure of José Luis, she endeavors to attain an encounter with someone who “could touch her essence, make her whole,” so that she might “return to the world, purified and strong” (Martínez, 1994, p. 68). José Luis inpires her to desire to be saved and to get a “whole new self” (Martínez, 1994, p. 86). In this manner, Mary attributes to him the absolute position.

\footnotetext{
${ }^{3}$ In "Religion as a Cultural System”, Geertz defines religion as "a system of symbols which acts to establish powerful, pervasive, and long-lasting moods and motivations in men by formulating conceptions of a general order of existence and clothing these conceptions with such an aura of factuality that the moods and motivations seem uniquely realistic" (Geertz, 1973, p. 4). His definition tells us that religion is to be "uniquely realistic" to practitioners due to its coherent network of signs and symbols in their entire culture. Therefore, his theoretical term, "thick description," entails the Wittgensteinian perspective on this network, which he conceptualizes as an entity with "stratified hierarchy of meaningful structures" playing in the "context of ongoing pattern of life". As the fusion of worldview and ethos at the core, this concept of religion is important to understand what I mean by the "sacred" here.
} 


\section{Conclusion}

In spite of the fact that these types of literary modes could be characterized as lacking psychological depth and having a propensity for overwhelming preoccupation with romantic love, the novel's involvement in the genre of romance and the melodramatic narrative ironically attests to Mary's striving for the spiritual ideal and ontological answer. Martínez may want to reveal Mary’s urgent necessity for relocating spiritual crisis by her employment of this style of narrative. In this sense, Mary's love can be read as representation of her loss of the sacred as well as a response to this loss. This story reveals that the primacy of the interpersonal realm is transformed into the sacred one where the protagonist admits transcendental occurrence.

Mother Tongue offers several intriguing avenues which emerge through the convergence of political and religious issues and the synthesis of the erotic and the spiritual. By subsuming herself in the mythic demands of romance, Mary makes him embody an otherness in her imagery. However, looking back at the relationship with José Luis from the present in the novel, Mary demonstrates her growth and awakening as she chronicles how she has healed herself as well as how she rediscovered her religiosity. Mother Tongue shows how the erotic encounter with the other is gradually transformed into a spiritual awakening.

\section{References}

Brooks, P. (1995). The melodramatic imagination. New Haven: Yale University Press.

Castillo, D., \& Tabuenca Córdoba, M. S. (2002). Border women: Writing from La Frontera. Minneapolis: University of Minnesota Press.

Duplessis, R. B. (1985). Writing beyond the ending. Bloomington: Indiana University Press.

Geertz, C. (1973). The interpretation of cultures. New York: Basic Books.

Heller, D. (1995). Housebreaking history: Feminism's troubled romance with the domestic sphere. In D. Elam and R. Wiegman (Eds.), Feminism beside itself. New York: Routledge.

Ikas, K. R. (2002). Chicana ways: Converstaions with ten Chicana writers. Reno: University of Nevada Press.

Martínez, D. (1994). Mother tougue. New York: Ballantine.

Strehle, S., \& Carden, M. P. (Eds.). (2003). Doubled plots: Romance and history. Jackson: University Press of Mississippi. 